\title{
Pengaruh Likuiditas, Struktur Modal, Ukuran Perusahaan, Prospek Pertumbuhan, Kualitas Audit Terhadap Kualitas Laba Perusahaan Batu Bara
}

\author{
Chandra Ferdinand Wijaya \\ email: chandra.ferdinand@unpar.ac.id \\ Universitas Katolik Parahyangan, Bandung
}

\begin{abstract}
Financial statements are a means used by company's management to communicate financial information to its users in order to assist decision making. Company's management has more information than shareholders. As a result, company's management tends to make earnings management for certain purposes. Such conditions reduce the quality of earnings presented in the financial statements. Some factors are expected to influence the tendency of companies to manipulate earnings that affect earnings quality. The purpose of this research is to examine the effect of liquidity, capital structure, company size, growth prospects, and audit quality on earnings quality. This research is a causal research. The population consists of coal mining subsector companies listed in Indonesia Stock Exchange during 2012 - 2016. This research uses simple random sampling and analysed by multiple linear regression. The result shows that liquidity, capital structure, company size, growth prospects, and audit quality have a significant effect simultaneously on earnings quality. The partial hypothesis testing shows that liquidity has no significant effect on earnings quality, while firm size and audit quality have a significant positive effect on earnings quality. The capital structure and growth prospects have a significant negative effect on earnings quality.
\end{abstract}

Keywords: Earnings Quality, Liquidity, Capital Structure, Company Size, Growth Prospect, and Audit Quality.

\section{PENDAHULUAN}

Laporan keuangan merupakan sarana bagi manajemen perusahaan untuk mengomunikasikan informasi keuangan yang berguna bagi para pengguna laporan keuangan (Wiryadi dan Sebrina, 2013). Pengguna laporan keuangan menggunakan informasi yang tersaji pada laporan keuangan untuk pengambilan keputusan ekonomi, misalnya pengambilan keputusan investasi saham dengan melihat informasi likuiditas dan leverage dari laporan keuangan perusahaan yang dipercaya sebagai faktor yang signifikan dalam menentukan tinggi rendahnya return atas investasi saham (Wijaya dan Djajadikerta, 2017) 
Laporan keuangan yang berguna harus menyajikan informasi keuangan yang relevan dan dapat diandalkan (Kadous, Koonce, dan Thayer, 2012). Salah satu informasi yang seringkali digunakan pengguna laporan keuangan dalam pengambilan keputusan adalah informasi laba. Informasi laba ini memberikan deskripsi mengenai kinerja perusahaan dan kinerja manajer (Wiryadi dan Sebrina, 2013).

Teori keagenan menyebutkan bahwa suatu perusahaan dimiliki oleh principal dan dikelola oleh manajemen yang bertindak sebagai agen dari principal (Lan dan Heracleous, 2010). Principal sebagai pemilik perusahaan menginginkan maksimalisasi kekayaan pemegang saham, sedangkan manajemen sebagai agen memiliki tujuan yang berbeda, misalnya menginginkan kompensasi yang tinggi dan seringkali tidak sejalan dengan cita-cita dari principal (Ahmed, 2009). Hal ini menunjukkan bahwa agen dan principal memiliki tujuannya masing-masing. Sebagai akibatnya, konflik keagenan antara principal dan manajemen perusahaan akan timbul dan dapat berdampak pada menurunnya kualitas laba.

Laporan keuangan disusun oleh pihak manajemen sehingga manajemen lebih memiliki akses akan informasi internal perusahaan daripada pemilik perusahaan (principal) (Wiryadi dan Sebrina, 2013). Sebagai akibatnya, manajemen perusahaan termotivasi untuk melakukan manipulasi laba dalam rangka mencapai tujuannya, misalnya memperoleh bonus yang tinggi tanpa memperhatikan dampak jangka panjangnya bagi perusahaan, khususnya principal. Manipulasi laba menurunkan kualitas laba dari laporan keuangan yang disajikan. Sebagai akibatnya, pengguna laporan keuangan, termasuk principal tidak dapat melakukan pengambilan keputusan dengan tepat.

Seiring dengan perkembangan pasar dan aturan pelaporan keuangan, maka pengguna laporan keuangan membutuhkan informasi keuangan yang lebih berkualitas sehingga dapat mengambil keputusan dengan baik. Oleh karena itu, kualitas laba menjadi fokus bagi pengguna laporan keuangan dalam pengambilan keputusan yang tepat. Kondisi ini mengakibatkan kualitas laba menjadi suatu topik yang layak untuk diperhatikan. 
Selama lima tahun yaitu tahun 2012 sampai dengan 2016, harga batu bara mengalami penurunan sehingga perusahaan batu bara sedang mengalami krisis dalam beberapa tahun terakhir (Tirto.id, 23 November 2016). Hal ini disebabkan karena anjloknya harga batu bara (Bisnis Indonesia, 1 September 2016). Kondisi yang demikian menyebabkan turunnya profitabilitas perusahaan batu bara sehingga terdapat kecenderungan menurunnya jumlah investor yang menanamkan dananya pada perusahaan dan bonus yang diterima manajemen pun menjadi menurun. Hal ini menjadi salah satu motivasi manajemen perusahaan batu bara untuk melakukan manajemen laba agar laporan keuangannya tampak baik sehingga pemegang saham dan calon investor tetap tertarik menanamkan dananya pada perusahaan dan manajemen dapat memperoleh bonus yang tinggi meskipun sedang dalam kondisi krisis (Cahyati, 2011). Oleh karena itu, penelitian ini akan difokuskan pada perusahaan-perusahaan yang bergerak pada sub sektor pertambangan batu bara.

Terdapat beberapa faktor yang diperkirakan memiliki dampak terhadap kualitas laba, yaitu likuiditas, struktur modal, ukuran perusahaan, prospek pertumbuhan, dan kualitas audit. Likuiditas dan struktur modal erat kaitannya dengan pendanaan perusahaan dari pihak eksternal. Karena erat kaitannya dengan pendanaan perusahaan dari pihak eksternal, maka likuiditas dan struktur modal mendeskripsikan risiko keuangan perusahaan. Risiko keuangan ini cenderung memotivasi perusahaan untuk melakukan manajemen laba sehingga likuiditas dan struktur modal merupakan faktor yang diperkirakan memengaruhi kualitas laba (Warianto dan Rusiti, 2014).

Ukuran perusahaan pun merupakan faktor yang tidak kalah pentingnya dalam menentukan kualitas laba. Perusahaan berskala besar dianggap lebih mampu meningkatkan kinerjanya dibandingkan perusahaan berskala kecil (Warianto dan Rusiti, 2014). Motivasi untuk melakukan manajemen laba didorong oleh ada tidaknya kemampuan untuk meningkatkan kinerja perusahaan sehingga ukuran perusahaan diyakini sebagai faktor yang memengaruhi kualitas laba. 
Prospek pertumbuhan perusahaan dapat menggambarkan peningkatan laba perusahaan di masa yang akan datang (Imroatussolihah, 2013). Dengan demikian prospek pertumbuhan dapat memberikan gambaran apakah suatu perusahaan dapat berkembang dengan baik atau tidak nantinya. Oleh karena itu, prospek pertumbuhan dipercaya sebagai faktor yang dapat memengaruhi motivasi dilakukannya manajemen laba. Oleh karenanya, prospek pertumbuhan diyakini sebagai faktor yang menentukan kualitas laba perusahaan.

Kualitas audit pun menjadi salah satu faktor yang diperkirakan memiliki dampak terhadap kualitas laba. Auditor merupakan pihak yang melakukan pemeriksaan akuntansi atas laporan keuangan perusahaan agar sesuai dengan prinsip akuntansi yang berlaku umum. Keberadaan auditor ini diyakini dapat membatasi manajemen perusahaan dalam melakukan praktik manajemen laba sehingga menjamin kualitas laba (Dechow, Ge, dan Schrand, 2010).

Penelitian mengenai pengaruh likuiditas, struktur modal, ukuran perusahaan, prospek pertumbuhan, dan kualitas audit terhadap kualitas laba telah dilakukan oleh beberapa peneliti dan memiliki hasil yang tidak konsisten antar satu peneliti dengan peneliti yang lainnya. Oleh karena itu, penelitian ini bertujuan untuk menguji kembali pengaruh likuiditas, struktur modal, ukuran perusahaan, prospek pertumbuhan, dan kualitas audit terhadap kualitas laba.

\section{TINJAUAN PUSTAKA}

\section{Teori Keagenan (Agency Theory)}

Teori keagenan berkaitan dengan suatu kondisi di mana principal menunjuk agen agar berlaku sebagai pihak yang melaksanakan pengelolaan organisasi dalam rangka mencapai tujuan principal, yaitu memaksimalkan kesejahteraan pemegang saham (Namazi, 2013). Baik principal maupun agen memiliki tujuannya masing-masing sehingga agen memiliki kecenderungan untuk melakukan aktivitas yang hanya mencapai tujuannya semata dan menghambat tercapainya tujuan principal (Agarwal, Goel, dan Vashishtha, 2014).

Principal memiliki tujuan memaksimalkan kesejahteraan pemegang saham. Di sisi lain, agen memiliki tujuan yang berbeda dengan principal, yaitu 
memaksimalkan kepentingan pribadinya. Sebagai pihak yang mengelola perusahaan, agen memiliki akses yang lebih banyak atas informasi internal perusahaan. Oleh karena itu, terdapat informasi asimetris antara agen dengan pemegang saham (Christiani dan Nugrahanti, 2014). Informasi asimetris ini kerapkali dimanfaatkan oleh manajemen perusahaan untuk melakukan manipulasi laba yang merendahkan kualitas laba (Dira dan Astika, 2014).

\section{Kualitas Laba}

Kualitas laba menunjukkan derajat informatif suatu informasi mengenai kinerja perusahaan. Kualitas laba yang tinggi memungkinkan disajikannya informasi yang relevan terkait kinerja suatu perusahaan sehingga pengguna informasi dapat mengambil keputusan dengan tepat (Dechow, Ge, dan Schrand, 2010). Laba dikatakan berkualitas apabila mencerminkan tiga karakteristik sebagai berikut (Warianto dan Rusiti, 2014):

a) Laba tersebut mampu mencerminkan kinerja operasional perusahaan saat ini dengan akurat.

b) Laba tersebut dapat menjadi indikator yang baik mengenai kinerja perusahaan di masa yang akan datang.

c) Dapat dijadikan sebagai ukuran yang baik dalam menilai kinerja perusahaan.

\section{Likuiditas}

Likuiditas merupakan kemampuan perusahaan untuk melunasi kewajiban jangka pendeknya dengan aset lancar yang dimiliki (Warianto dan Rusiti, 2014). Likuiditas harus dapat dikelola perusahaan dengan baik. Likuiditas yang terlalu tinggi menunjukkan adanya kecenderungan pengelolaan aset lancar yang tidak maksimal oleh manajemen perusahaan (Dira dan Astika, 2014).

\section{Struktur Modal}

Struktur modal menunjukkan seberapa besar aset suatu perusahaan dibiayai oleh utang (Dira dan Astika, 2014). Perusahaan dengan tingkat utang yang tinggi menanggung risiko keuangan yang tinggi pula. Risiko keuangan 
tersebut merupakan risiko gagal bayar di mana perusahaan tidak mampu melunasi kewajiban-kewajibannya (Warianto dan Rusiti, 2014).

Perusahaan yang melakukan pendanaan dari utang memiliki perjanjian yang harus dipenuhi terkait ukuran-ukuran akuntansinya. Debt covenant hypothesis menjelaskan bahwa suatu perusahaan yang telah mendekati pelanggaran persyaratan utang akan lebih cenderung memilih prosedur akuntansi yang memindahkan laba periode masa yang akan datang ke periode sekarang (Jao dan Pagalung, 2011). Hal ini dilakukan agar ukuran-ukuran akuntansi yang tersaji pada laporan keuangan selalu memenuhi persyaratan yang disepakati antara perusahaan dengan kreditor.

\section{Ukuran Perusahaan}

Ukuran perusahaan merupakan skala besar kecilnya perusahaan (Warianto dan Rusiti, 2014). Ukuran perusahaan dapat dilihat dari total asetnya. Semakin besar aset suatu perusahaan, maka ukuran perusahaan tersebut semakin besar.

Perusahaan berskala besar cenderung lebih diperhatikan oleh masyarakat. Hal ini menyebabkan perusahaan tersebut cenderung berhati-hati dalam pelaporan keuangan (Jao dan Pagalung, 2011).

\section{Prospek Pertumbuhan}

Prospek pertumbuhan merupakan peluang suatu perusahaan bertumbuh di masa yang akan datang (Hermuningsih, 2013). Perusahaan yang memiliki pertumbuhan tinggi cenderung meningkatkan aset tetapnya sehingga lebih banyak membutuhkan dana dan cenderung menahan laba untuk mendanai aset-asetnya dalam rangka mengembangkan perusahaan (Hermuningsih, 2013).

\section{Kualitas Audit}

Audit merupakan suatu proses yang dilakukan untuk memastikan bahwa informasi yang disajikan pada laporan keuangan suatu perusahaan benar-benar bersifat objektif, dapat diandalkan, dan dapat dipercaya (Wiryadi dan Sebrina, 2013). Luaran dari proses audit adalah berupa opini audit yang menjelaskan kesesuaian laporan keuangan dengan standar pelaporan yang berlaku. 
Opini audit menjadi salah satu alat yang penting bagi para pengguna informasi laporan keuangan dalam pengambilan keputusan. Oleh karena itu, kualitas audit merupakan hal penting agar dapat dihasilkannya opini audit yang relevan dan dapat diandalkan (Guna dan Herawaty, 2010). Kualitas audit merupakan peluang bahwa auditor tidak akan mengeluarkan opini audit wajar tanpa pengecualian untuk laporan keuangan yang mengandung kekeliruan bersifat material (Wiryadi dan Sebrina, 2013).

\section{Penelitian Terdahulu}

Penelitian mengenai topik kualitas laba telah dilakukan oleh beberapa peneliti dan memiliki hasil yang tidak konsisten.

Tabel 1

Penelitian Terdahulu

\begin{tabular}{|c|c|c|c|c|c|}
\hline \multirow[b]{2}{*}{ Peneliti } & \multicolumn{5}{|c|}{ Kualitas Laba } \\
\hline & Likuiditas & $\begin{array}{c}\text { Struktur } \\
\text { Modal }\end{array}$ & $\begin{array}{c}\text { Ukuran } \\
\text { Perusahaan }\end{array}$ & $\begin{array}{c}\text { Prospek } \\
\text { Pertumbuhan }\end{array}$ & $\begin{array}{c}\text { Kualitas } \\
\text { Audit }\end{array}$ \\
\hline $\begin{array}{c}\text { Sadiah dan Priyadi } \\
\text { (2015) }\end{array}$ & $\begin{array}{c}\text { Tidak } \\
\text { signifikan }\end{array}$ & $\begin{array}{c}\text { Tidak } \\
\text { signifikan }\end{array}$ & (-) Signifikan & NA & $\mathrm{NA}$ \\
\hline $\begin{array}{c}\text { Christiani dan } \\
\text { Nugrahanti (2014) }\end{array}$ & NA & $\begin{array}{c}\text { Tidak } \\
\text { signifikan }\end{array}$ & NA & (-) Signifikan & $\begin{array}{c}\text { Tidak } \\
\text { signifikan }\end{array}$ \\
\hline Dira dan Astika (2014) & $\begin{array}{c}\text { Tidak } \\
\text { signifikan }\end{array}$ & $\begin{array}{c}\text { Tidak } \\
\text { signifikan }\end{array}$ & (+) Signifikan & Tidak signifikan & NA \\
\hline $\begin{array}{l}\text { Warianto dan Rusiti } \\
\text { (2014) }\end{array}$ & $\begin{array}{c}(+) \\
\text { Signifikan }\end{array}$ & $\begin{array}{c}(-) \\
\text { Signifikan }\end{array}$ & (+) Signifikan & $\mathrm{NA}$ & NA \\
\hline $\begin{array}{l}\text { Wiryadi dan Sebrina } \\
\text { (2013) }\end{array}$ & NA & NA & NA & NA & $\begin{array}{c}\text { Tidak } \\
\text { signifikan }\end{array}$ \\
\hline $\begin{array}{c}\text { Jao dan Pagalung } \\
\text { (2011) }\end{array}$ & NA & $\begin{array}{c}\text { Tidak } \\
\text { signifikan }\end{array}$ & (+) Signifikan & NA & NA \\
\hline $\begin{array}{l}\text { Namazi dan Khanzalar } \\
\text { (2011) }\end{array}$ & NA & NA & NA & (-) Signifikan & NA \\
\hline Valipour dan & $\mathrm{NA}$ & $(-)$ & NA & NA & NA \\
\hline Moradbeygi (2011) & & Signifikan & & & \\
\hline $\begin{array}{l}\text { Guna dan Herawaty } \\
\text { (2010) }\end{array}$ & NA & NA & $\begin{array}{c}\text { Tidak } \\
\text { signifikan }\end{array}$ & NA & $\begin{array}{c}(+) \\
\text { Signifikan }\end{array}$ \\
\hline
\end{tabular}

Sumber: berbagai jurnal 


\section{Pengaruh Likuiditas Terhadap Kualitas Laba}

Perusahaan yang memiliki likuiditas baik cenderung untuk tidak melakukan manipulasi laba. Hal ini disebabkan karena likuiditas menunjukkan kemampuan perusahaan untuk melunasi kewajiban jangka pendeknya. Hal tersebut direspon sebagai suatu kinerja keuangan yang baik oleh para pengguna laporan keuangan (Warianto dan Rusiti, 2014). Sebagai akibatnya, praktik manajemen laba cenderung untuk tidak dilakukan. Dengan demikian, semakin tinggi likuiditas perusahaan, maka kualitas laba semakin baik.

\section{Pengaruh Struktur Modal Terhadap Kualitas Laba}

Teori keagenan menjelaskan bahwa terdapat informasi asimetris antara kreditor dengan perusahaan. Oleh karenanya, kreditor tidak mengetahui secara pasti aktivitas yang dilakukan oleh perusahaan sehingga terdapat kecenderungan bagi manajemen untuk melakukan manajemen laba (Birjandi, Hakemi, dan Sadeghi, 2015). Tingginya tingkat utang perusahaan menggambarkan tingginya risiko keuangan perusahaan, yaitu risiko gagal bayar (Warianto dan Rusiti, 2014). Risiko gagal bayar menunjukkan kemungkinan perusahaan tidak mampu membayar utang-utangnya. Menurut debt covenant hypothesis, semakin dekat perusahaan ke arah pelanggaran persyaratan utang, maka manajer perusahaan akan cenderung melakukan manipulasi laba (Jao dan Pagalung, 2011). Oleh karena itu, semakin tinggi tingkat utang, maka kecenderungan perusahaan untuk melakukan manajemen laba semakin tinggi agar laporan keuangannya tampak baik dan tidak melanggar persyaratan utang. Dengan demikian, semakin tinggi tingkat utang dalam struktur modal perusahaan, maka kualitas laba semakin rendah.

\section{Pengaruh Ukuran Perusahaan Terhadap Kualitas Laba}

Perusahaan berskala besar memiliki kemampuan yang lebih besar untuk mempertahankan bahkan mengembangkan pangsa pasarnya (Birjandi, Hakemi, dan Sadeghi, 2015). Sebagai akibatnya, kelangsungan usaha perusahaan berskala besar lebih terjamin dalam meningkatkan kinerjanya (Dira dan Astika, 2014). 
Oleh karena itu, semakin besar ukuran perusahaan, maka kecenderungan perusahaan untuk melakukan manipulasi laba semakin kecil sehingga kualitas laba semakin baik.

\section{Pengaruh Prospek Pertumbuhan Terhadap Kualitas Laba}

Perusahaan dengan tingkat pertumbuhan yang tinggi akan cenderung untuk menahan pembayaran dividen tunai karena adanya kecenderungan untuk menyimpan dan menginvestasikan dananya pada hal-hal yang dapat digunakan untuk mengembangkan perusahaannya (Namazi dan Khansalar, 2011). Perusahaan yang demikian berusaha untuk tetap memikat investor dengan cara memberikan gambaran yang baik pada laporan keuangannya sehingga perusahaan seolah selalu tampak berkembang dan investor tetap mau membeli sahamnya dalam rangka menerima capital gain jangka panjang di masa yang akan datang meskipun adanya retensi atas dividen. Oleh karena itu, perusahaan dengan prospek pertumbuhan tinggi cenderung melakukan manajemen laba (Christiani dan Nugrahanti, 2014). Dengan demikian, semakin tinggi prospek pertumbuhan perusahaan, maka kualitas labanya akan semakin rendah.

\section{Pengaruh Kualitas Audit Terhadap Kualitas Laba}

Teori keagenan menjelaskan bahwa agen lebih memiliki banyak informasi daripada principal sehingga terjadi kondisi yang disebut dengan informasi asimetris. Kondisi informasi asimetris tersebut meningkatkan kecenderungan untuk melakukan manajemen laba. Audit yang berkualitas perlu dilakukan dalam rangka mencegah terjadinya manajemen laba (Christiani dan Nugrahanti, 2014). Keberadaan auditor yang berkualitas meningkatkan kemungkinan untuk mendeteksi praktik manajemen laba sehingga menurunkan kecenderungan manajemen untuk melakukan manajemen laba. Oleh karena itu, semakin tinggi kualitas audit, maka kualitas laba perusahaan semakin baik.

\section{Hipotesis Penelitian}

Hipotesis penelitian ini adalah sebagai berikut: 
$\mathrm{H}_{1}$ : Likuiditas, struktur modal, ukuran perusahaan, prospek pertumbuhan, dan kualitas audit berpengaruh signifikan terhadap kualitas laba secara simultan.

$\mathrm{H}_{2}$ : Likuiditas berpengaruh positif signifikan secara parsial terhadap kualitas laba.

$\mathrm{H}_{3} \quad$ : Struktur modal berpengaruh negatif signifikan secara parsial terhadap kualitas laba.

$\mathrm{H}_{4} \quad$ : Ukuran perusahaan berpengaruh positif signifikan secara parsial terhadap kualitas laba.

$\mathrm{H}_{5} \quad$ : Prospek pertumbuhan berpengaruh negatif signifikan secara parsial terhadap kualitas laba.

$\mathrm{H}_{6} \quad$ : Kualitas audit berpengaruh positif signifikan secara parsial terhadap kualitas laba.

\section{METODE PENELITIAN}

Penelitian yang akan dilakukan ini merupakan causal research yang dianalisis secara kuantitatif. Populasi dalam penelitian ini adalah perusahaanperusahaan yang terdaftar dalam Bursa Efek Indonesia dan termasuk ke dalam sub sektor pertambangan batu bara selama tahun 2012-2016. Periode penelitian ini dipilih karena pada 5 tahun tersebut harga batu bara sedang mengalami penurunan. Berdasarkan populasi tersebut, peneliti melakukan pengambilan sampel penelitian secara simple random sampling dan diperoleh 15 perusahaan sebagai sampel penelitian.

Variabel yang digunakan dalam penelitian ini adalah sebagai berikut:

1) Variabel dependen

Variabel dependen pada penelitian ini adalah kualitas laba.

Kualitas laba diproksikan dengan discretionary accruals menggunakan model Modified Jones (Warianto dan Rusiti, 2014). Perhitungan discretionary accruals adalah sebagai berikut:

a) Total Accruals

TACCit $=$ NIit - OCFit 
Kemudian, lakukan estimasi parameter spesifik perusahaan dengan menggunakan model:

$\frac{T A C C_{i t}}{T A_{i, t-1}}=\alpha_{1} \frac{1}{T A_{i, t-1}}+\alpha_{2} \frac{\left(\Delta R E V_{i t}-\triangle R E C_{i t}\right)}{T A_{i, t-1}}+\alpha_{3} \frac{P P E_{i t}}{T A_{i, t-1}}$

b) Non Discretionary Accruals

$$
\mathrm{NDACC}_{\mathrm{it}}=\alpha_{1} \frac{1}{T A_{i, t-1}}+\alpha_{2} \frac{\left(\Delta R E V_{i t}-\Delta R E C_{i t}\right)}{\mathrm{T} A_{i, t-1}}+\alpha_{3} \frac{P P E_{i t}}{T A_{i, t-1}}
$$

c) Discretionary Accruals

$\mathrm{DACC}_{\mathrm{it}}=\left(\mathrm{TACC}_{\mathrm{it}} / \mathrm{TA}_{\mathrm{i}, \mathrm{t}-1}\right)-\mathrm{NDACC}_{\mathrm{it}}$

Keterangan:

TACC $_{\text {it }} \quad$ : Total accruals perusahaan i periode $\mathrm{t}$

$\mathrm{NI}_{\mathrm{it}} \quad$ : Laba bersih perusahaan i periode $\mathrm{t}$

$\mathrm{OCF}_{\text {it }} \quad:$ Arus kas aktivitas operasi perusahaan i periode $\mathrm{t}$

$\mathrm{TA}_{\mathrm{i}, \mathrm{t}-1} \quad$ : Total aset perusahaan i periode $\mathrm{t}-1$

$\Delta \operatorname{Rev}_{\text {it }} \quad$ : Perubahan pendapatan perusahaan i dari periode

$\mathrm{t}-1$ ke periode $\mathrm{t}$

$\Delta \operatorname{Rec}_{i t} \quad:$ Perubahan piutang perusahaan i dari periode $\mathrm{t}-1$ ke periode $\mathrm{t}$

$\mathrm{PPE}_{\mathrm{it}} \quad:$ Aset tetap kotor perusahaan i periode $\mathrm{t}$

$\mathrm{NDACC}_{\mathrm{it}} \quad$ : Non discretionary accruals perusahaan i periode $\mathrm{t}$

$\alpha_{1,2,3} \quad$ : Parameter estimasi

DACC $_{\text {it }} \quad$ : Discretionary accruals perusahaan i periode $\mathrm{t}$

2) Variabel independen

Variabel independen pada penelitian ini terdiri atas:

a) Likuiditas diukur dengan Current Ratio (CR) dan dihitung dengan rumus (Warianto dan Rusiti, 2014):

Current Ratio $=\frac{\text { Current Assets }}{\text { Current Liabilities }}$

b) Struktur modal diukur dengan Debt Ratio (DAR) dan dihitung dengan rumus (Warianto dan Rusiti, 2014): 


$$
\mathrm{DAR}=\frac{\text { Total Liabilities }}{\text { Total Assets }}
$$

c) Ukuran perusahaan diukur dengan logaritma natural dari total aset perusahaan (Warianto dan Rusiti, 2014).

d) Prospek pertumbuhan perusahaan diukur dengan Market to Book Value Ratio (Christiani dan Nugrahanti, 2014). Rasio tersebut dihitung dengan rumus:

Market to book value $(\mathrm{MBV})=\frac{\text { Market price per share }}{\text { Book value per share }}$

e) Kualitas audit diukur dengan menggunakan variabel dummy yang ditentukan berdasarkan kategori auditor eksternal yang melakukan pemeriksaan akuntansi atas perusahaan terkait. Kategori auditor eksternal dibagi menjadi dua kategori, yaitu auditor Big Four dan non Big Four (Wiryadi dan Sebrina, 2013).

Taraf signifikansi $(\alpha)$ yang digunakan dalam penelitian ini adalah $5 \%$. Data-data pada penelitian ini dianalisis dengan menggunakan regresi linear berganda. Model regresi dalam penelitian ini adalah:

$\mathrm{DACC}_{\mathrm{it}}=\beta_{0}+\beta_{1} \mathrm{CR}_{\mathrm{it}}+\beta_{2} \mathrm{DAR}_{\mathrm{it}}+\beta_{3} \mathrm{SIZE}_{\mathrm{it}}+\beta_{4} \mathrm{MBV}_{\mathrm{it}}+\beta_{5} \mathrm{KAP}_{\mathrm{it}}+\mathrm{e}_{\mathrm{it}}$

Keterangan:

DACC $_{\text {it }} \quad$ : Discretionary Accruals saham i periode $\mathrm{t}$

$\beta_{0} \quad$ : konstanta

$\beta_{1,2,3,4,5} \quad$ : koefisien regresi

$\mathrm{e}_{\mathrm{it}} \quad$ : error

$\mathrm{CR}_{\mathrm{it}} \quad$ : Current Ratio perusahaan i periode $\mathrm{t}$

DAR $_{\text {it }} \quad$ : Debt Ratio perusahaan i periode $\mathrm{t}$

$\mathrm{SIZE}_{\text {it }} \quad:$ Ukuran perusahaan perusahaan i periode $\mathrm{t}$

$\mathrm{MBV}_{\text {it }} \quad$ : Market to Book Value perusahaan i periode $\mathrm{t}$

$\mathrm{KAP}_{\mathrm{it}} \quad:$ Kategori auditor eksternal perusahaan i periode $\mathrm{t}$

Analisis regresi linear berganda menggunakan teknik Ordinary Least Square sehingga model regresi yang dianalisis harus memenuhi asumsi klasik 
(Ghozali, 2013: 96). Uji asumsi klasik terdiri atas uji normalitas, uji multikolinearitas, uji autokorelasi, dan uji heteroskedastisitas.

Setelah model regresi memenuhi kriteria asumsi klasik, maka langkah berikutnya adalah melakukan uji hipotesis, baik secara simultan dan parsial. Variabel independen dikatakan memiliki pengaruh secara simultan terhadap variabel dependen apabila nilai p-value (Sig) dari uji F lebih kecil dari taraf signifikansi yang telah ditetapkan dalam penelitian ini, yaitu 5\% (Ghozali, 2013:98). Sedangkan, variabel independen dikatakan memiliki pengaruh signifikan secara parsial terhadap variabel dependen apabila nilai p-value (Sig) variabel independen lebih kecil daripada taraf signifikansi yang ditetapkan dalam penelitian ini, yaitu 5\% (Ghozali, 2013:98).

\section{HASIL DAN PEMBAHASAN}

\section{Uji Normalitas}

Berikut merupakan hasil dari uji normalitas:

Tabel 2

Hasil Uji Normalitas

\begin{tabular}{lr}
\hline & $\begin{array}{c}\text { Unstandardized } \\
\text { Residual }\end{array}$ \\
\hline Kolmogorov-Smirnov Z & 1,219 \\
\hline Asymp. Sig. (2-tailed) & 0,102 \\
\hline Sumber: Hasil olah data &
\end{tabular}

Berdasarkan hasil uji Kolmogorov-Smirnov, dapat dilihat bahwa p-value bernilai 0,102 . Nilai tersebut berada di atas 0,05 yang merupakan $\alpha$ pada penelitian ini, sehingga dapat disimpulkan bahwa data residual berdistribusi normal.

\section{Uji Multikolinearitas}

Berikut ini merupakan hasil uji multikolinearitas: 
Tabel 3

\begin{tabular}{|c|c|c|}
\hline \multicolumn{3}{|c|}{ Hasil Uji Multikolinearitas } \\
\hline \multirow{2}{*}{ Variabel Independen } & \multicolumn{2}{|c|}{ Collinearity Statistics } \\
\hline & Tolerance & VIF \\
\hline $\mathrm{CR}$ & 0,678 & 1,475 \\
\hline$\overline{\mathrm{DAR}}$ & 0,483 & 2,070 \\
\hline SIZE & 0,710 & 1,409 \\
\hline PBV & 0,853 & 1,172 \\
\hline KAP & 0,646 & 1,549 \\
\hline
\end{tabular}

Sumber: Hasil olah data

Berdasarkan uji multikolinearitas yang dilakukan, besarnya Tolerance untuk masing-masing variabel independen berada di atas 0,10 dan besarnya VIF untuk masing-masing variabel independen berada di bawah 10. Hal ini menunjukkan bahwa tidak terjadi multikolinearitas di antara kelima variabel independen.

\section{Uji Autokorelasi}

Berikut ini merupakan hasil uji autokorelasi:

\section{Tabel 4}

\section{Hasil Uji Autokorelasi}

Breusch-Godfrey Serial Correlation LM Test:

Obs*R-squared $\quad 74,50905$ Prob. Chi-Square $\quad 0,0985$

Sumber: Hasil olah data

Bila nilai prob. Chi-Square berada di atas $\alpha$, maka tidak terjadi autokorelasi (Ghozali dan Ratmono, 2013:144). Berdasarkan hasil uji autokorelasi yang dilakukan, besarnya $p$-value adalah 0,0985. Nilai tersebut berada di atas 0,05 yang merupakan $\alpha$ pada penelitian ini, sehingga dapat disimpulkan bahwa model regresi tidak mengalami autokorelasi.

\section{Uji Heteroskedastisitas}

Berikut ini merupakan hasil uji heteroskedastisitas: 
Tabel 5

\section{Hasil Uji Heteroskedastisitas}

\section{Heteroskedasticity Test: White}

Obs*R-squared $\quad 11,05821$ Prob. Chi-Square $\quad 0,0502$

\section{Sumber: Hasil olah data}

Bila nilai prob. Chi-Square berada di atas $\alpha$, maka tidak terjadi heteroskedastisitas (Ghozali dan Ratmono, 2013:106). Berdasarkan hasil uji heteroskedastisitas yang dilakukan, besarnya $p$-value berada di atas 0,05 yang merupakan $\alpha$ pada penelitian ini. Hal ini menunjukkan bahwa model regresi tidak mengalami heteroskedastisitas.

Hasil uji asumsi klasik yang telah dilakukan menunjukkan bahwa model regresi yang digunakan dalam penelitian ini telah memenuhi kriteria asumsi klasik. Dengan demikian, tahap selanjutnya adalah melakukan pengujian hipotesis penelitian. Hasil pengujian hipotesis penelitian ditunjukkan pada tabel berikut ini:

\section{Tabel 6}

\section{Hasil Uji Signifikansi Parsial dan Simultan}

\begin{tabular}{lccl}
\hline & $\boldsymbol{\beta}$ & $\mathbf{T}$ & Sig. \\
\hline Constant & 10,354 & 3,231 & 0,002 \\
\hline CR & 0,049 & 0,432 & 0,667 \\
\hline DAR & 1,144 & 2,264 & 0,027 \\
\hline SIZE & $-0,350$ & $-3,071$ & 0,003 \\
\hline PBV & 0,129 & 2,265 & 0,027 \\
\hline KAP & $-0,646$ & $-2,190$ & 0,032 \\
\hline F statistic $=2,616$ & & &
\end{tabular}

Sig. $\mathrm{F}=0,032$

Sumber: Hasil olah data

Berdasarkan hasil uji signifikansi parsial dan simultan, nilai $p$-value dari F-statistic bernilai 0,032 . Nilai tersebut berada di bawah 0,05 . Oleh karena itu, likuiditas, struktur modal, ukuran perusahaan, prospek pertumbuhan, dan kualitas audit berpengaruh signifikan secara simultan terhadap kualitas laba. Dengan demikian, $\mathrm{H}_{1}$ diterima, artinya likuiditas, struktur modal, ukuran perusahaan, prospek pertumbuhan, dan kualitas audit merupakan faktor yang secara bersama- 
sama memengaruhi kualitas laba perusahaan, khususnya perusahaan yang termasuk dalam sub sektor pertambangan batu bara. Dengan demikian, pengguna laporan keuangan harus memerhatikan faktor-faktor tersebut secara bersama dalam mempertimbangkan menentukan kualitas laba sebagai upayanya untuk melakukan pengambilan keputusan.

Berdasarkan hasil uji signifikansi parsial dan simultan, nilai $p$-value dari likuiditas (CR) adalah 0,667. Nilai tersebut lebih besar daripada 0,05 sehingga $\mathrm{H}_{2}$ ditolak. Dengan demikian, likuiditas tidak berpengaruh signifikan terhadap kualitas laba. Hasil tersebut sejalan dengan penelitian yang dilakukan oleh Warianto dan Rusiti (2014).

Berdasarkan hasil uji signifikansi parsial dan simultan, nilai $p$-value dari struktur modal (DAR) adalah 0,027. Nilai tersebut lebih kecil daripada 0,05 sehingga struktur modal memiliki pengaruh yang signifikan terhadap kualitas laba. Koefisien regresi ( $\beta$ ) untuk struktur modal (DAR) bernilai positif terhadap discretionary accruals, artinya semakin besar struktur modal, maka discretionary accruals akan semakin besar. Discretionary accruals yang besar menunjukkan kualitas laba yang rendah. Dengan demikian, struktur modal berpengaruh negatif signifikan secara parsial terhadap kualitas laba perusahaan sub sektor pertambangan batu bara, atau dengan kata lain $\mathrm{H}_{3}$ diterima. Dengan demikian, struktur modal berpengaruh negatif signifikan terhadap kualitas laba. Hasil tersebut sejalan dengan penelitian yang dilakukan oleh Warianto dan Rusiti (2014) serta Valipour dan Moradbeygi (2011).

Berdasarkan hasil uji signifikansi parsial dan simultan, nilai $p$-value dari ukuran perusahaan (SIZE) adalah 0,003. Nilai tersebut lebih kecil daripada 0,05 sehingga ukuran perusahaan memiliki pengaruh yang signifikan terhadap kualitas laba. Koefisien regresi $(\beta)$ untuk variabel ukuran perusahaan (SIZE) bernilai negatif terhadap discretionary accruals, artinya semakin besar ukuran perusahaan, maka discretionary accruals akan semakin kecil. Discretionary accruals yang kecil menunjukkan kualitas laba yang tinggi. Dengan demikian, ukuran perusahaan berpengaruh positif signifikan secara parsial terhadap kualitas laba perusahaan sub sektor pertambangan batu bara, atau dengan kata lain $\mathrm{H}_{4}$ diterima. 
Hasil tersebut sejalan dengan penelitian yang dilakukan oleh Dira dan Astika (2014), Warianto dan Rusiti (2014), serta Jao dan Pagalung (2011).

Berdasarkan hasil uji signifikansi parsial dan simultan, nilai $p$-value dari prospek pertumbuhan (PBV) adalah 0,027. Nilai tersebut lebih kecil daripada 0,05 sehingga prospek pertumbuhan memiliki pengaruh signifikan terhadap kualitas laba. Koefisien regresi $(\beta)$ untuk variabel prospek pertumbuhan (PBV) bernilai positif terhadap discretionary accruals, artinya semakin besar prospek pertumbuhan, maka discretionary accruals akan semakin besar. Discretionary accruals yang besar menunjukkan kualitas laba yang rendah. Dengan demikian, prospek pertumbuhan berpengaruh negatif signifikan secara parsial terhadap kualitas laba perusahaan sub sektor pertambangan batu bara, atau dengan kata lain $\mathrm{H}_{5}$ diterima. Hasil tersebut sejalan dengan penelitian yang dilakukan oleh Christiani dan Nugrahanti (2014), serta Namazi dan Khanzalar (2011).

Berdasarkan hasil uji signifikansi parsial dan simultan, nilai $p$-value dari kualitas audit (KAP) adalah 0,032. Nilai tersebut lebih kecil daripada 0,05 sehingga kualitas audit memiliki pengaruh signifikan terhadap kualitas laba. Koefisien regresi ( $\beta$ ) untuk variabel kualitas audit (KAP) bernilai negatif terhadap discretionary accruals, artinya semakin berkualitas audit yang dilakukan, maka discretionary accruals akan semakin kecil. Discretionary accruals yang kecil menunjukkan kualitas laba yang tinggi. Dengan demikian, kualitas audit berpengaruh positif signifikan secara parsial terhadap kualitas laba perusahaan sub sektor pertambangan batu bara, atau dengan kata lain $\mathrm{H}_{6}$ diterima. Hasil tersebut sejalan dengan penelitian yang dilakukan oleh Guna dan Herawaty (2010).

\section{KESIMPULAN DAN SARAN}

Berdasarkan hasil penelitian, dapat disimpulkan hal sebagai berikut:

1) Likuiditas, struktur modal, ukuran perusahaan, prospek pertumbuhan, dan kualitas audit berpengaruh signifikan terhadap kualitas laba perusahaan sub sektor pertambangan batu bara secara simultan.

2) Likuiditas tidak berpengaruh signifikan terhadap kualitas laba perusahaan sub sektor pertambangan batu bara secara parsial. 
3) Struktur modal berpengaruh negatif signifikan terhadap kualitas laba perusahaan sub sektor pertambangan batu bara secara parsial.

4) Ukuran perusahaan berpengaruh positif signifikan terhadap kualitas laba perusahaan sub sektor pertambangan batu bara secara parsial.

5) Prospek pertumbuhan berpengaruh negatif signifikan terhadap kualitas laba perusahaan sub sektor pertambangan batu bara secara parsial.

6) Kualitas audit berpengaruh positif signifikan terhadap kualitas laba perusahaan sub sektor pertambangan batu bara secara parsial.

Penelitian ini memiliki keterbatasan, yaitu hanya dilakukan pada perusahaan-perusahaan sub sektor pertambangan batu bara. Oleh karena itu, peneliti selanjutnya disarankan dapat mengembangkan penelitian yang serupa dengan menambah periode waktu penelitian dan melibatkan sektor-sektor industri yang lainnya dalam penelitian.

\section{DAFTAR PUSTAKA}

Agarwal, Shubhi, Rohit Goel, dan Pushpendra Kumar Vashishta. (2014). A Literature Review of Agency Theory. Paripex - Indian Journal of Research, 3 (5): $51-52$.

Ahmed, Huson Joher Ali. (2009). Managerial Ownership Concertration and Agency Conflict using Logistic Regression Approach: Evidence from Bursa Malaysia. Journal of Management Research, 1 (1): 1 - 10.

Birjandi, Hamid, Behruz Hakemi, dan Mohammad Mehdi Molla Sadeghi. (2015). The Study Effect Agency Theory and Signaling Theory on The Level of Voluntary Disclosure of Listed Companies in Tehran Stock Exchange. Research Journal of Finance and Accounting. 6 (1): 174 - 183.

Bisnis Indonesia. (2016). Kinerja Emiten Tambang: Daftar Perusahaan Batu Bara, Siapa Jawara \& Merana?. Diunduh pada 2 Juli 2017, dari http://market.bisnis.com/read/20160901/192/580196/kinerja-emiten-tambangdaftar-perusahaan-batu-bara-siapa-jawara-merana. 
Cahyati, Ari Dewi. (2011). Peluang Manajemen Laba Pasca Konvergensi IFRS: Sebuah Tinjauan Teoritis dan Empiris. JRAK: Jurnal Riset Akuntansi \& Komputerisasi Akuntansi, 2(1): 1 - 7 .

Christiani, Ingrid dan Yeterina Widi Nugrahanti. (2014). Pengaruh Kualitas Audit Terhadap Manajemen Laba. Jurnal Akuntansi dan Keuangan, 16 (1): 52-62.

Dechow, Patricia, Weili Ge, dan Catherine Schrand. (2010). Understanding Earnings Quality: A Review of The Proxies, Their Determinants, and Their Consequences. Journal of Accounting and Economics, 50: 344 - 401.

Dira, Kadek Prawisanti dan Ida Bagus Putra Astika. (2014). Pengaruh Struktur Modal, Likuiditas, Pertumbuhan Laba, dan Ukuran Perusahaan Pada Kualitas Laba. E-Journal Akuntansi Universitas Udayana, 7 (1): 64 - 78.

Ghozali, Imam. (2013). Aplikasi Analisis Multivariate dengan Program IBM SPSS 21 ( $7^{\text {th }}$ ed.). Semarang: Universitas Diponegoro.

Ghozali, Imam dan Dwi Ratmono. (2013). Analisis Multivariat dan Ekonometrika. Semarang: Universitas Diponegoro.

Guna, Welvin I. dan Arleen Herawaty. (2010). Pengaruh Mekanisme Good Corporate Governance, Independensi Auditor, Kualitas Audit, dan Faktor Lainnya Terhadap Manajemen Laba. Jurnal Bisnis dan Akuntansi, 12 (1): 5368.

Hermuningsih, Sri. (2013). Pengaruh Profitabilitas, Growth Opportunity, Struktur Modal Terhadap Nilai Perusahaan Pada Perusahaan Publik di Indonesia. Buletin Ekonomi Moneter dan Perbankan, Oktober 2013, 128 - 143.

Imroatussolihah, Ely. (2013). Pengaruh Risiko, Leverage, Peluang Pertumbuhan, Persistensi Laba dan Kualitas Tanggung Jawab Sosial Perusahaan Terhadap Earning Response Coefficient Pada Perusahaan High Profile. Jurnal Ilmiah Manajemen, 1 (1): 75 - 87. 
Jao, Robert dan Gagaring Pagalung. (2011). Corporate Governance, Ukuran Perusahaan, dan Leverage Terhadap Manajemen Laba Perusahaan Manufaktur Indonesia. Jurnal Akuntansi \& Auditing, 8 (1): 43 - 54.

Kadous, Kathryn, Lisa Koonce, dan Jane M. Thayer. (2012). Do Financial Statement Users Judge Relevance Based on Properties of Reliability?. The Accounting Review, 87 (4): 1335 - 1356.

Lan, Luh Luh dan Loizos Heracleous. (2010). Rethinking Agency Theory: The View From Law. Academy of Management Review, 35 (2): 294 - 314.

Namazi, Mohammad. (2013). Role of The Agency Theory in Implementing Management's Control. Journal of Accounting and Taxation, 5 (2): 38 - 47.

Namazi, Mohammad dan Ehsan Khansalar. (2011). An Investigation of The Income Smoothing Behavior of Growth and Value Firms (Case Study: Tehran Stock Exchange Market). International Business Research, 4 (4): 84 - 93.

Sadiah, Halimatus dan Maswar Patuh Priyadi. (2015). Pengaruh Leverage, Likuiditas, Size, Pertumbuhan Laba, dan IOS Terhadap Kualitas Laba. Jurnal Ilmu \& Riset Akuntansi, 4 (5).

Sekaran, Uma dan Roger Bougie. (2010). Research Method for Business: A Skill Building Approach ( $5^{\text {th }}$ ed.). New York: John Wiley \& Sons.

Tirto.id. (2016). Menanti Akhir dari Bisnis Batu Bara. Diunduh pada 2 Juli 2017, dari https://tirto.id/menanti-akhir-dari-bisnis-batu-bara-b5wb.

Valipour. Hashem dan Mehdi Moradbeygi. (2011). Corporate Debt Financing and Earnings Quality. Journal of Applied Finance \& Banking, 1 (3): 139 - 157.

Warianto, Paulina dan Ch. Rusiti. (2014). Pengaruh Ukuran Perusahaan, Struktur Modal, Likuiditas, dan Investment Opportunity Set (IOS) Terhadap Kualitas Laba Pada Perusahaan Manufaktur Yang Terdaftar Di BEI. Modus, 26 (1): 19 32. 
JEMAP: Jurnal Ekonomi, Manajemen, Akuntansi, dan Perpajakan ISSN: 2622-612X (Media Online) | Vol.3 | No.2 | Oktober 2020

Wijaya, Chandra Ferdinand dan Hamfri Djajadikerta. (2017). Pengaruh Risiko Sistematis, Leverage, dan Likuiditas Terhadap Return Saham LQ 45 yang Terdaftar Pada Bursa Efek Indonesia. Ultima Management, 9 (2): 62 - 76.

Wiryadi, Arri dan Nurzi Sebrina. (2013). Pengaruh Asimetri Informasi, Kualitas Audit, dan Struktur Kepemilikan Terhadap Manajemen Laba. Wahana Riset Akuntansi, 1 (2): 155 - 180. 